\title{
Lung Cancer in Pulmonary Fibrosis: Tales of Epithelial Cell Plasticity
}

\author{
Melanie Königshoff \\ Comprehensive Pneumology Center, Ludwig Maximilians University, University Hospital Grosshadern, \\ and Helmholtz Zentrum München, Munich, Germany
}

\section{Key Words}

Pulmonary fibrosis · Lung cancer · Alveolar epithelium

\begin{abstract}
Lung epithelial cells exhibit a high degree of plasticity. Alterations to lung epithelial cell function are critically involved in several chronic lung diseases such as pulmonary fibrosis. Pulmonary fibrosis is characterized by repetitive injury and subsequent impaired repair of epithelial cells, which leads to aberrant growth factor activation and fibroblast accumulation. Increased proliferation and hyper- and metaplasia of epithelial cells upon injury have also been observed in pulmonary fibrosis; this epithelial cell activation might represent the basis for lung cancer development. Indeed, several studies have provided histopathological evidence of an increased incidence of lung cancer in pulmonary fibrosis. The mechanisms involved in the development of cancer in pulmonary fibrosis, however, remain poorly understood. This review highlights recently uncovered molecular mechanisms shared between lung cancer and fibrosis, which extend the current evidence of a common trait of cancer and fibrosis, as provided by histopathological observations.
\end{abstract}

Copyright ๑ 2011 S. Karger AG, Basel

\section{Introduction}

Lung epithelial cells form a tight functional barrier which is essential for the maintenance of normal lung function throughout life [1]. The alveolar epithelium is composed of alveolar epithelial type I (ATI) and type II (ATII) cells. ATII cells are cuboidal secretory cells mainly responsible for surfactant secretion, thereby reducing surface tension [2]. In addition, ATII cells have been implicated in lung defense mechanisms due to cytokine release and antioxidant production. ATII cells supposedly serve as progenitors, initiating the restoration of alveolar epithelium in the adult lung by either giving rise to new ATII cells or differentiating into ATI cells [3]. While lesser in number, ATI cells cover over $95 \%$ of the alveolar surface area, thereby providing the basis for gas exchange [4]. Alveolar epithelial cells exhibit a high degree of plasticity and are involved in injury, repair, and transforma-

Previous articles in this series: 1 . Rooney C, Sethi T: The epithelial cell and lung cancer: the link between chronic obstructive pulmonary disease and lung cancer. Respiration 2011;81:89-104. 2. Adcock IM, Caramori G, Barnes PJ: COPD and lung cancer: new molecular insights. Respiration 2011;81:265-284.

\section{KARGER \\ Fax +4161306 1234 \\ E-Mail karger@karger.ch}

www.karger.com
(C) 2011 S. Karger AG, Basel

$0025-7931 / 11 / 0815-0353 \$ 38.00 / 0$

Accessible online at:

www.karger.com/res
Melanie Königshoff, $\mathrm{MD}, \mathrm{PhD}$

Comprehensive Pneumology Center, Ludwig Maximilians University Munich University Hospital Grosshadern, and Helmholtz Zentrum München Max-Lebsche-Platz 31, DE-81377 München (Germany)

Tel. +49893187 4668, E-Mail melanie.koenigshoff@ helmholtz-muenchen.de 
tion processes of the lung. Alveolar epithelial cell injury and impaired repair have been linked to several chronic lung diseases such as pulmonary fibrosis [5].

Idiopathic pulmonary fibrosis (IPF) represents one of the most common and progressive fibrotic disorders; it is characterized by repetitive injury and subsequent impaired repair of alveolar epithelial cells. This leads to aberrant growth factor activation and perpetuation of the fibrotic transformation and aggregation of activated myofibroblasts (fibroblast foci), which promote excessive extracellular matrix deposition [6, 7]. Hyperplastic proliferating alveolar epithelial cells are frequently found in IPF, and alveolar epithelial cell proliferation may be involved in impaired repair mechanisms [8-10].

These observations strongly suggest that fibrotic epithelial cells may serve as a possible origin of carcinoma development. Other histological cell atypies that have been observed in IPF include bronchiolization as well as squamous and bronchial basal cell metaplasia that are similar to premalignant lesions in the bronchial epithelium $[11,12]$. Along this line, Chilosi et al. [8] reported abnormal proliferation of bronchial epithelial cells in IPF but not in other interstitial pneumonias such as acute or nonspecific pneumonias.

Several studies have provided histopathological evidence of an increased incidence of lung cancer in IPF. Hironaka et al. [13] found that squamous metaplasia occurred more frequently in patients with usual interstitial pneumonia (the histopathological correlate of IPF) and lung cancer compared with usual interstitial pneumonia without lung cancer. Epidemiological studies have reported a prevalence of lung cancer in up to $30 \%$ of pulmonary fibrosis cases [14]. Further, the role of cigarette smoking as an established risk factor for both IPF and lung cancer has been investigated in several studies [11, $15,16]$. It has been reported that IPF patients with lung cancer exhibit a significantly higher smoking index than do IPF patients without lung cancer. Interestingly, Hubbard et al. [17] provided evidence that the increased prevalence of lung cancer in IPF is independent of smoking. In the analyzed cohort, the incidence of lung cancer was significantly increased in IPF patients even after adjustment for previous smoking history.

Of further interest is the histological localization of tumors within the fibrotic lung. Most cancer cases have been identified in the lung periphery and lower lobes, closely located to fibrotic changes which predominantly occur within these areas $[11,12]$. Histologically, different subtypes of lung cancer such as small cell carcinoma, adenocarcinoma, or squamous cell carcinoma have been re- ported often, but not exclusively, in nontypical locations in the lung periphery $[18,19]$.

The real incidence and occurrence of lung cancer in pulmonary fibrosis, however, may very likely be underestimated for several reasons: (1) the nontypical localization of tumors in the lower lobes, which may hamper its radiological detection in pulmonary fibrosis, particularly since previous studies have only been performed upon autopsy, (2) the current reassessment of the classification of idiopathic interstitial pneumonias, which limits retrospective analysis due to differences in diagnostic accuracy and nomenclature, and (3) the progressive course of IPF with an overall survival of $2-4$ years after diagnosis and no proven therapeutic option, which may lead to the fact that IPF patients may die before lung cancer develops or is detected.

Clearly, the mechanisms involved in the development of cancer remain poorly understood. Recent advances in our understanding of the molecular mechanisms involved in pulmonary fibrosis have complemented the histopathological evidence and provided a deeper insight into the possible pathomechanisms involved in lung cancer development in patients with pulmonary fibrosis. The aim of this review, therefore, is to highlight these novel findings linking pulmonary fibrosis with lung cancer.

\section{Epithelial Cell Phenotype in Pulmonary Fibrosis}

The findings that lung epithelial cells from fibrotic lungs appear hyper- and metaplastic in IPF $[8,20,21]$ has been further examined by ultrastructural studies that revealed the existence of proliferative alveolar epithelial cells immediately adjacent to injured and apoptotic epithelial cells [22-24]. The simultaneous occurrence of epithelial apoptosis, hyperplasia, and proliferation is also a consistent finding in experimental lung fibrosis $[25,26]$, suggesting that an ongoing injury repair process in fibrosis represents the basis for lung cancer development. These results have been further corroborated on the cellular level. Primary alveolar epithelial cells isolated from fibrotic lungs exhibited an increased proliferative capacity and enhanced gene expression of proliferative mediators [27].

Importantly, several genes and pathways which have been assigned an oncogenic role, such as the WNT/ $\beta$ catenin signaling pathway, have been found to be altered in these cells. In addition, fibrotic primary alveolar epithelial cells have been shown to exhibit an enhanced migratory ability and may undergo epithelial-to-mesenchymal transition (EMT), a mechanism which further links fibrosis and cancer development [27-29] (fig. 1). 
Fig. 1. Potential mechanisms involved in lung cancer development in pulmonary fibrosis. Alterations in the epithelial cell phenotype, such as dysplasia, proliferation, or EMT, may be driven by oncogenic signal pathways that are aberrantly activated in pulmonary fibrosis.

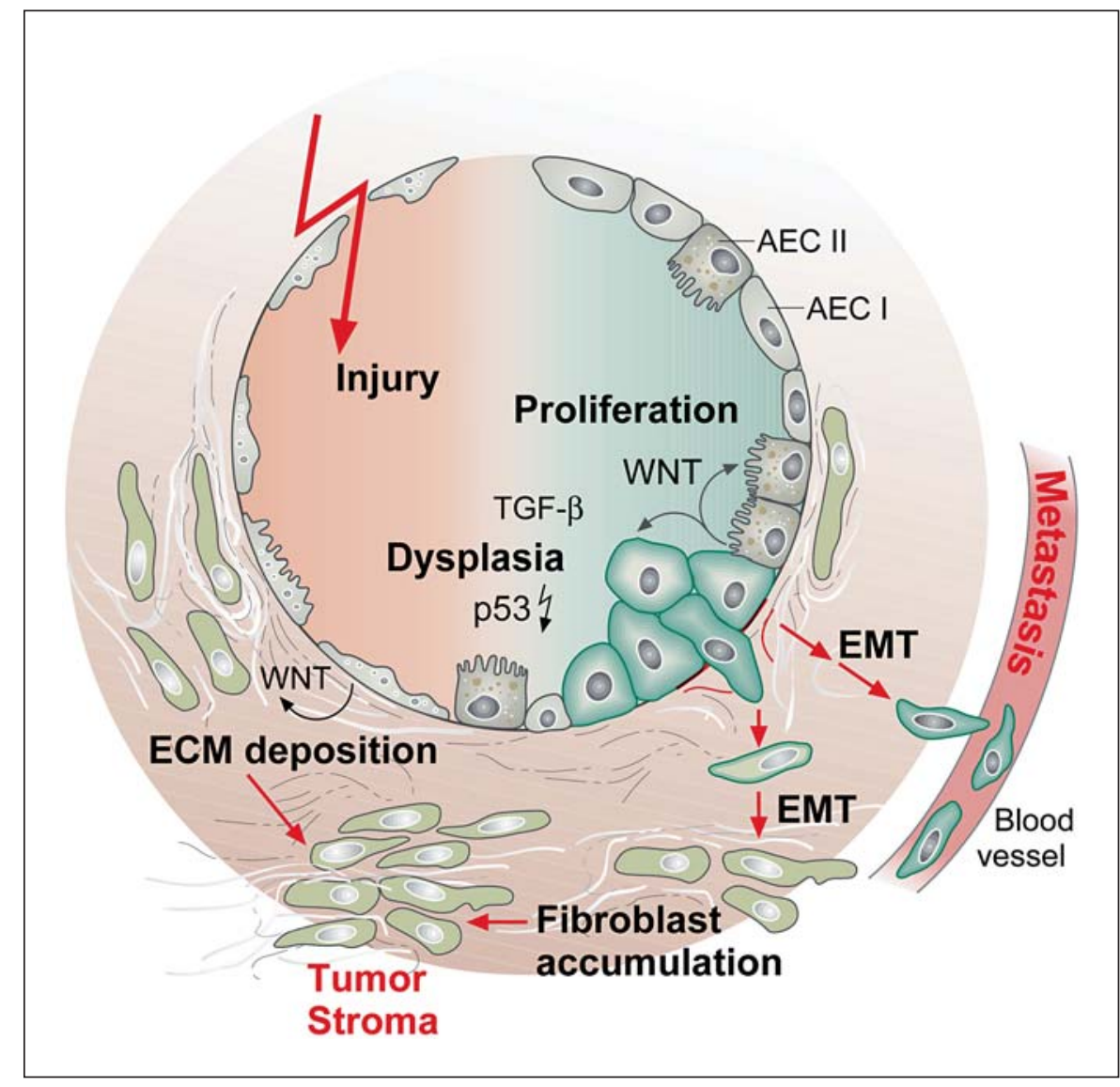

\section{Epithelial-to-Mesenchymal Transition}

EMT is defined as the reversible phenotypic alteration of an epithelial into a fibroblast-like cell and has been described in the process of embryonic development, cancerogenesis, and organ fibrosis [30,31]. The EMT process is characterized by changes in cell polarity, remodeling of cell-cell and cell-matrix adhesion contacts, loss of epithelial cell markers, induction of mesenchymal gene expression, and reorganization of the actin cytoskeleton with a subsequent enhanced ability for cell migration [31,32].

In lung cancer, EMT has been described in the context of cancer invasion and metastasis, and it has been proposed to be a survival strategy for cells to avoid induction of apoptosis by drug treatment $[33,34]$. In vivo evidence, however, documenting that EMT is involved in lung cancer progression is still missing. In pulmonary fibrosis, epithelial cells, via the process of EMT, possibly serve as a source for the increased (myo-)fibroblast pool [35]. Recent studies have demonstrated evidence of EMT in IPF tissue specimens as well as in allografts after lung trans- plantation [36]. Colocalization of epithelial and mesenchymal marker expression in hyperplastic alveolar epithelial cells in lung tissue from IPF patients suggested that EMT significantly contributes to IPF pathogenesis [28]. One of the main inducers of EMT is transforming growth factor (TGF)- $\beta$, a cytokine also implicated in cancer metastasis [37]. It has been demonstrated that TGF- $\beta$ induces EMT in alveolar epithelial cells in vitro and in vivo $[28,29,38]$. Upon exposure to TGF- $\beta$, alveolar epithelial cells gain mesenchymal marker gene expression while loosing epithelial markers, indicative of EMT [39]. Recently, TGF- $\beta$-induced EMT was also demonstrated in vivo in a triple transgenic mouse model [29].

Enhanced cellular migration is closely linked with EMT [31]. Matrix metalloproteinases (MMP) are critically involved in these processes by cleaving extracellular matrix proteins and activating growth factor signaling. Altered MMP expression has been reported in wound healing, organ fibrosis, and cancer development [40, 41]. Matrilysin (MMP7) is expressed and secreted by lung epithelial cells and has been found to be upregulated in hu- 
man and experimental fibrosis [42]. MMP7 is known to be a WNT/ $\beta$-catenin target gene and has further been suggested to promote invasiveness in lung cancer [43]. How MMP expression may foster cancer development in fibrosis has been reported in transgenic animal models in which overexpression of MMP3 or membrane type-1 (MT1)-MMP led to increased collagen deposition and fibrosis followed by tumorigenesis in the breast [44, 45]. Similar mechanisms may be relevant for the lung but have not been reported thus far.

In summary, the ability of lung epithelial cells to express MMP, migrate, and undergo EMT warrants future studies to determine the temporal and spatial role that EMT may play in the development of lung cancer within pulmonary fibrosis.

\section{Oncogenic Signaling Pathways}

Cancer develops via a multistep process involving tumor suppressors as well as oncogenes that trigger the transition of normal epithelial cells to metaplastic and subsequently carcinoma cells [46]. This paragraph focuses on tumor suppressors as well as oncogenes that have been implicated in pulmonary fibrosis and cancer alike.

First, the well-known tumor suppressor protein p53 is altered in squamous metaplasia and dysplastic bronchial and alveolar epithelium in patients with IPF $[47,48]$. It has been demonstrated that chronic epithelial cell injury coincides with the upregulation of p53 and p21 and subsequent (impaired) repair may lead to point mutations within the p53 gene, resulting in a loss of function [47, 49]. This may represent an early trigger of epithelial cell transformation and tumorigenesis. In addition, expression of a truncated isoform of p63 (deltaN-p63) has been reported at sites of epithelial hyperplasia, squamous metaplasia, bronchiolization, and abnormal p53 nuclear accumulation in IPF [8].

Aberrant expression of developmentally active signaling pathways is a common and well-investigated feature of cancer, but this mechanism has been largely underappreciated in nonmalignant diseases. Recently, these oncogenic pathways have been uncovered in the development and progression of pulmonary fibrosis [50, 51]. One of the most prominent pathways is the highly conserved $\mathrm{WNT} / \beta$-catenin signaling pathway, which has been found to be aberrantly activated in chronic fibrotic lung disease $[52,53]$. The $\mathrm{WNT} / \beta$-catenin signaling pathway constitutes a large family of secreted glycoproteins that signal via a variety of membrane-bound receptors. In short, in the presence of WNT ligands, the membrane receptors frizzled (FZD) and low-density lipoprotein receptor-related protein (LRP) 5 or 6 are activated upon WNT binding. WNT ligand binding to FZD and LRP leads to the phosphorylation of LRP6 by glycogen synthase kinase (GSK)-3 $\beta$ and casein kinase $\gamma$ in its cytoplasmic region, which leads to the recruitment of the cytosolic proteins dishevelled (DVL) 1-3 and axin. Subsequently, $\beta$-catenin phosphorylation is inhibited and its degradation attenuated. Accumulated $\beta$-catenin undergoes nuclear translocation and regulates target gene expression via interaction with members of the T-cellspecific transcription factor/lymphoid enhancer-binding factor (TCF/LEF) family [54].

Chilosi et al. [53] reported nuclear localization of $\beta$ catenin in the hyperplastic alveolar epithelium, as well as interstitium in IPF, indicative of activated WNT/ $\beta$-catenin signaling. In addition, it has been recently demonstrated that several components of the canonical $\mathrm{WNT} / \beta$-catenin signaling pathway are overexpressed in human IPF [52] as well as in experimental lung fibrosis [27]. Interestingly, canonical WNT/ $\beta$-catenin signaling components (including WNT ligands, $\beta$-catenin, or GSK-3 $\beta$ ) localized mainly to the bronchial and alveolar epithelium. Increased activity of the WNT/ $\beta$ catenin pathway in IPF was documented by increased phosphorylation of LRP6 and GSK-3 $\beta$. In addition, several WNT target genes such as MMP7 or fibronectin are differentially expressed in IPF, [42]. Activation of canonical $\mathrm{WNT} / \beta$-catenin signaling has been further demonstrated in experimental lung fibrosis in vivo [27, $55,56]$. A whole genome microarray screen from primary alveolar epithelial cells isolated from fibrotic mouse lungs revealed an 'oncogene signature' including WNT components and target genes but also from other pathways [27]. In particular, increased expression of the WNT target gene WNT-inducible signaling pathway protein (WISP) 1 has been found in hyperplastic proliferating alveolar epithelial cells [57]. WISP1 led to enhanced epithelial proliferation and migration as well as EMT. WNT ligands themselves lead to an increased proliferation of bronchial and alveolar epithelial cells in vitro. The impact of $\mathrm{WNT} / \beta$-catenin signaling as a regulator of EMT has been demonstrated by the direct participation of $\beta$-catenin in these processes $[58,59]$ as well as by induction of EMT by Wnt ligands in vitro [60]. Although in vivo evidence is still missing, the aforementioned data highlight the WNT/ $\beta$-catenin pathway and its target gene WISP1 as possible mediators of lung cancer development in pulmonary fibrosis (fig. 1). Indeed, 
WISP1 alterations have been reported in lung cancer specimens [61-63]. In addition, increased activity of the upstream $\mathrm{WNT} / \beta$-catenin pathway has also been reported. Several studies have reported increased nuclear $\beta$-catenin staining in several lung tumor samples. Changes in the expression of several Wnt components (such as Wnt1, Wnt2, and Dvl3) have been reported in non-small cell lung carcinoma and associated with enhanced cell growth and/or resistance to apoptotic therapies [64]. Additional studies have demonstrated that Wnt regulators are transcriptionally silenced in nonsmall cell lung carcinoma, thereby promoting tumor growth $[65,66]$.

Altogether, these studies represent profound evidence that links active WNT/ $\beta$-catenin signaling with alveolar and bronchial epithelial cell injury and repair. Future studies are needed to further elucidate the effects and mechanisms of active $\mathrm{WNT} / \beta$-catenin signaling and to analyze whether this pathway plays a causative role in lung cancer development in pulmonary fibrosis.

\section{Conclusion}

Pulmonary fibrosis is characterized by repetitive cycles of epithelial cell injury followed by impaired epithelial cell repair. Phenotypic alterations, such as hyper- and metaplasia, have been described in IPF and strongly suggest that fibrotic epithelial cells may be able to further transform, thereby representing a possible origin of carcinoma development. Although an increased incidence of lung cancer in pulmonary fibrosis has been reported, this field warrants further investigation. Recent advances in our understanding of the molecular mechanisms of pulmonary fibrosis have complemented the histopathological evidence. Processes such as EMT or (re-)activation of oncogenic pathways have been implicated in pulmonary fibrosis development, in particular in alveolar epithelial cell injury und repair mechanisms. These novel findings provide further evidence on the molecular and cellular level of a close link between pulmonary fibrosis and lung cancer.

\section{References}

$>1$ Matthay MA, Robriquet L, Fang X: Alveolar epithelium: role in lung fluid balance and acute lung injury. Proc Am Thorac Soc 2005; 2:206-213.

-2 Dobbs LG, Johnson MD: Alveolar epithelial transport in the adult lung. Respir Physiol Neurobiol 2007;159:283-300.

3 Mason RJ: Biology of alveolar type II cells. Respirology 2006;11(suppl): S12-S15.

$\checkmark 4$ Herzog EL, Brody AR, Colby TV, Mason R, Williams MC: Knowns and unknowns of the alveolus. Proc Am Thorac Soc 2008;5:778782.

5 Selman M, Pardo A: Role of epithelial cells in idiopathic pulmonary fibrosis: from innocent targets to serial killers. Proc Am Thorac Soc 2006;3:364-372.

6 Maher TM, Wells AU, Laurent GJ: Idiopathic pulmonary fibrosis: multiple causes and multiple mechanisms? Eur Respir J 2007;30: 835-839.

7 Thannickal VJ, Horowitz JC: Evolving concepts of apoptosis in idiopathic pulmonary fibrosis. Proc Am Thorac Soc 2006;3:350 356.

$\checkmark 8$ Chilosi M, Poletti V, Murer B, Lestani M, Cancellieri A, et al: Abnormal re-epithelialization and lung remodeling in idiopathic pulmonary fibrosis: the role of deltaN-p63. Lab Invest 2002;82:1335-1345.

$>9$ Kasper M, Haroske G: Alterations in the alveolar epithelium after injury leading to pulmonary fibrosis. Histol Histopathol 1996;11: 463-483.
10 Qunn L, Takemura T, Ikushima S, Ando T, Yanagawa T, et al: Hyperplastic epithelial foci in honeycomb lesions in idiopathic pulmonary fibrosis. Virchows Arch 2002;441: 271-278.

11 Aubry MC, Myers JL, Douglas WW, Tazelaar HD, Washington Stephens TL, et al: Primary pulmonary carcinoma in patients with idiopathic pulmonary fibrosis. Mayo Clin Proc 2002;77:763-770.

12 Nagai A, Chiyotani A, Nakadate T, Konno K: Lung cancer in patients with idiopathic pulmonary fibrosis. Tohoku J Exp Med 1992; 167:231-237.

13 Hironaka M, Fukayama M: Pulmonary fibrosis and lung carcinoma: a comparative study of metaplastic epithelia in honeycombed areas of usual interstitial pneumonia with or without lung carcinoma. Pathol Int 1999;49:1060-1066.

14 Artinian V, Kvale PA: Cancer and interstitial lung disease. Curr Opin Pulm Med 2004;10: 425-434.

15 Baumgartner KB, Samet JM, Stidley CA, Colby TV, Waldron JA: Cigarette smoking: a risk factor for idiopathic pulmonary fibrosis. Am J Respir Crit Care Med 1997;155:242248.

16 Bai JW, Deng WW, Wu HC: The effect of montelukast on airway remodeling and the expression of interleukins and transforming growth factor-beta2 mRNA (in Chinese). Zhonghua Jie He He Hu Xi Za Zhi 2004;27: 524-528.
17 Hubbard R, Venn A, Lewis S, Britton J: Lung cancer and cryptogenic fibrosing alveolitis: a population-based cohort study. Am J Respir Crit Care Med 2000;161:5-8.

18 Park J, Kim DS, Shim TS, Lim CM, Koh Y, et al: Lung cancer in patients with idiopathic pulmonary fibrosis. Eur Respir J 2001;17: 1216-1219.

-19 Kawasaki H, Nagai K, Yokose T, Yoshida J, Nishimura M, et al: Clinicopathological characteristics of surgically resected lung cancer associated with idiopathic pulmonary fibrosis. J Surg Oncol 2001;76:53-57.

20 Haddad R, Massaro D: Idiopathic diffuse interstitial pulmonary fibrosis (fibrosing alveolitis), atypical epithelial proliferation and lung cancer. Am J Med 1968;45:211-219.

-21 Pan LH, Yamauchi K, Uzuki M, Nakanishi T, Takigawa M, et al: Type II alveolar epithelial cells and interstitial fibroblasts express connective tissue growth factor in IPF. Eur Respir J 2001;17:1220-1227.

$\checkmark 22$ Brody AR, Craighead JE: Interstitial associations of cells lining air spaces in human pulmonary fibrosis. Virchows Arch A Pathol Anat Histol 1976;372:39-49.

23 Coalson JJ: The ultrastructure of human fibrosing alveolitis. Virchows Arch A Pathol Anat Histopathol 1982;395:181-199.

24 Corrin B, Dewar A: Pathogenesis of idiopathic interstitial pulmonary fibrosis. Ultrastruct Pathol 1996;20:369-371. 
-25 Fukuda Y, Ferrans VJ, Schoenberger CI, Rennard SI, Crystal RG: Patterns of pulmonary structural remodeling after experimental paraquat toxicity: the morphogenesis of intraalveolar fibrosis. Am J Pathol 1985;118: 452-475.

26 Adamson IY, Young L, Bowden DH: Relationship of alveolar epithelial injury and repair to the induction of pulmonary fibrosis. Am J Pathol 1988;130:377-383.

-27 Königshoff M, Kramer M, Balsara N, Wilhelm J, Amarie OV, et al: WNT1-inducible signaling protein-1 mediates pulmonary fibrosis in mice and is upregulated in humans with idiopathic pulmonary fibrosis. J Clin Invest 2009;119:772-787.

-28 Willis BC, Liebler JM, Luby-Phelps K, Nicholson AG, Crandall ED, et al: Induction of epithelial-mesenchymal transition in alveolar epithelial cells by transforming growth factor-beta1:potential role in idiopathic pulmonary fibrosis. Am J Pathol 2005; 166:13211332.

-29 Kim KK, Kugler MC, Wolters PJ, Robillard L, Galvez MG, et al: Alveolar epithelial cell mesenchymal transition develops in vivo during pulmonary fibrosis and is regulated by the extracellular matrix. Proc Natl Acad Sci USA 2006;103:13180-13185.

30 Lee JM, Dedhar S, Kalluri R, Thompson EW: The epithelial-mesenchymal transition: new insights in signaling, development, and disease. J Cell Biol 2006;172:973-981.

- 31 Thiery JP: Epithelial-mesenchymal transitions in development and pathologies. Curr Opin Cell Biol 2003;15:740-746.

- 32 Zavadil J, Bottinger EP: TGF-beta and epithelial-to-mesenchymal transitions. Oncogene 2005;24:5764-5774.

- 33 Huber MA, Kraut N, Beug H: Molecular requirements for epithelial-mesenchymal transition during tumor progression. Curr Opin Cell Biol 2005;17:548-558.

- 34 Dasari V, Gallup M, Lemjabbar H, Maltseva I, McNamara N: Epithelial-mesenchymal transition in lung cancer: is tobacco the 'smoking gun'? Am J Respir Cell Mol Biol 2006;35:3-9.

35 Willis BC, BorokZ: TGF-beta-induced EMT: mechanisms and implications for fibrotic lung disease. Am J Physiol Lung Cell Mol Physiol 2007;293:L525-L534.

-36 Willis BC, duBois RM, Borok Z: Epithelial origin of myofibroblasts during fibrosis in the lung. Proc Am Thorac Soc 2006;3:377-382.

-37 Pennison M, Pasche B: Targeting transforming growth factor-beta signaling. Curr Opin Oncol 2007;19:579-585.

- 38 Kasai H, Allen JT, Mason RM, Kamimura T, Zhang Z: TGF-beta1 induces human alveolar epithelial to mesenchymal cell transition (EMT). Respir Res 2005;6:56.

- 39 Jayachandran A, Königshoff M, Yu H, Rupniewska E, Hecker M, et al: SNAI transcription factors mediate epithelial-mesenchymal transition in lung fibrosis. Thorax 2009;64:1053-1061.
$40 \mathrm{Hu}$ J, Van den Steen PE, Sang QX, Opdenakker G: Matrix metalloproteinase inhibitors as therapy for inflammatory and vascular diseases. Nat Rev Drug Discov 2007;6:480-498.

41 Radisky DC, Przybylo JA: Matrix metalloproteinase-induced fibrosis and malignancy in breast and lung. Proc Am Thorac Soc 2008;5:316-322.

42 Rosas IO, Richards TJ, Konishi K, Zhang Y, Gibson K, et al: MMP1 and MMP7 as potential peripheral blood biomarkers in idiopathic pulmonary fibrosis. PLoS Med 2008;5:e93.

-43 Huang CL, Liu D, Ishikawa S, Nakashima T, Nakashima N, et al: Wnt1 overexpression promotes tumour progression in non-small cell lung cancer. Eur J Cancer 2008;44:26802688.

$44 \mathrm{Ha} \mathrm{HY,} \mathrm{Moon} \mathrm{HB,} \mathrm{Nam} \mathrm{MS,} \mathrm{Lee} \mathrm{JW,} \mathrm{Ryoo}$ $\mathrm{ZY}$, et al: Overexpression of membrane-type matrix metalloproteinase-1 gene induces mammary gland abnormalities and adenocarcinoma in transgenic mice. Cancer Res 2001;61:984-990.

45 Sternlicht MD, Lochter A, Sympson CJ, Huey $\mathrm{B}$, Rougier JP, et al: The stromal proteinase MMP3/stromelysin-1 promotes mammary carcinogenesis. Cell 1999;98:137-146.

46 Sato M, Shames DS, Gazdar AF, Minna JD: A translational view of the molecular pathogenesis of lung cancer. J Thorac Oncol 2007; 2:327-343.

47 Kuwano K, Kunitake R, Kawasaki M, Nomoto Y, Hagimoto N, et al: P21Waf1/Cip1/Sdi1 and $\mathrm{p} 53$ expression in association with DNA strand breaks in idiopathic pulmonary fibrosis. Am J Respir Crit Care Med 1996;154: 477-483.

48 Kawasaki H, Ogura T, Yokose T, Nagai K, Nishiwaki Y, et al: p53 gene alteration in atypical epithelial lesions and carcinoma in patients with idiopathic pulmonary fibrosis. Hum Pathol 2001;32:1043-1049.

-49 Plataki M, Koutsopoulos AV, Darivianaki K, Delides G, Siafakas NM, et al: Expression of apoptotic and antiapoptotic markers in epithelial cells in idiopathic pulmonary fibrosis. Chest 2005;127:266-274.

-50 Selman M, Pardo A, Kaminski N: Idiopathic pulmonary fibrosis: aberrant recapitulation of developmental programs? PLoS Med 2008;5:e62.

-51 Königshoff M, Eickelberg O: WNT signaling in lung disease: a failure or a regeneration signal? Am J Respir Cell Mol Biol 2010;42:21-31.

-52 Königshoff M, Balsara N, Pfaff EM, Kramer M, Chrobak I, et al: Functional Wnt signaling is increased in idiopathic pulmonary fibrosis. PLoS One 2008;3:e2142.

53 Chilosi M, Poletti V, Zamo A, Lestani M, Montagna L, et al: Aberrant Wnt/betacatenin pathway activation in idiopathic pulmonary fibrosis. Am J Pathol 2003;162: 1495-1502.
54 Moon RT, Kohn AD, De Ferrari GV, Kaykas A: WNT and beta-catenin signalling: diseases and therapies. Nat Rev Genet 2004;5:691701.

55 Liu L, Carron B, Yee HT, Yie TA, Hajjou M, et al: Wnt pathway in pulmonary fibrosis in the bleomycin mouse model. J Environ Pathol Toxicol Oncol 2009;28:99-108.

56 Flozak AS, Lam AP, Russell S, Jain M, Peled ON, et al: Beta-catenin/T-cell factor signaling is activated during lung injury and promotes the survival and migration of alveolar epithelial cells. J Biol Chem 2010;285:31573167.

57 Berschneider B, Königshoff M: WNT1 inducible signaling pathway protein 1 (WISP1): a novel mediator linking development and disease. Int J Biochem Cell Biol. 2011;43: 306-309.

$58 \mathrm{Kim} \mathrm{K,} \mathrm{Lu} \mathrm{Z,} \mathrm{Hay} \mathrm{ED:} \mathrm{Direct} \mathrm{evidence} \mathrm{for} \mathrm{a}$ role of beta-catenin/LEF-1 signaling pathway in induction of EMT. Cell Biol Int 2002; 26:463-476.

59 Kato N, Shimmura S, Kawakita T, Miyashita $\mathrm{H}$, Ogawa $\mathrm{Y}$, et al: Beta-catenin activation and epithelial-mesenchymal transition in the pathogenesis of pterygium. Invest Ophthalmol Vis Sci 2007;48:1511-1517.

60 Dissanayake SK, Wade MS, Johnson CE, O'Connell M P, Leotlela PD, et al: The WNT5A/ PKC pathway mediates motility in melanoma cells via the inhibition of metastasis suppressors, and initiation of an epithelial to mesenchymal transition. J Biol Chem. 2007;282:17259-17271.

61 Chen PP, Li WJ, Wang Y, Zhao S, Li DY, et al Expression of Cyr61, CTGF, and WISP-1 correlates with clinical features of lung cancer. PLoS One 2007;2:e534.

62 Margalit O, Eisenbach L, Amariglio N, Kaminski N, Harmelin A, et al: Overexpression of a set of genes, including WISP-1, common to pulmonary metastases of both mouse D122 Lewis lung carcinoma and B16-F10.9 melanoma cell lines. Br J Cancer 2003;89: 314-319.

63 Soon LL, Yie TA, Shvarts A, Levine AJ, Su F, et al: Overexpression of WISP-1 down-regulated motility and invasion of lung cancer cells through inhibition of Rac activation. J Biol Chem 2003;278:11465-11470.

64 Mazieres J, He B, You L, Xu Z, Jablons DM: Wnt signaling in lung cancer. Cancer Lett 2005;222:1-10.

65 Uematsu K, He B, You L, Xu Z, McCormick $F$, et al: Activation of the Wnt pathway in non small cell lung cancer: evidence of dishevelled overexpression. Oncogene 2003;22: 7218-7221.

66 Kim J, You L, Xu Z, Kuchenbecker K, Raz D, et al: Wnt inhibitory factor inhibits lung cancer cell growth. J Thorac Cardiovasc Surg 2007;133:733-737. 